OPEN ACCESS

Edited by:

Lawrence Toll,

Florida Atlantic University,

United States

Reviewed by:

Brian Reed

Rockefeller University, United States

Marian L. Logrip

Indiana University, Purdue University

Indianapolis, United States

*Correspondence:

Sulie L. Chang

Sulie.chang@shu.edu

Specialty section:

This article was submitted to

Psychopharmacology,

a section of the journal

Frontiers in Psychiatry

Received: 31 July 2018

Accepted: 20 December 2018

Published: 22 January 2019

Citation:

Chang SL, Huang W, Han H and Sariyer IK (2019) Binge-Like Exposure

to Ethanol Enhances Morphine's

Anti-nociception in B6 Mice.

Front. Psychiatry 9:756

doi: 10.3389/fpsyt.2018.00756

\section{Binge-Like Exposure to Ethanol Enhances Morphine's Anti-nociception in B6 Mice}

\author{
Sulie L. Chang ${ }^{1,2 *}$, Wenfei Huang ${ }^{1,2}$, Haijun Han $^{1}$ and Ilker K. Sariyer ${ }^{3}$ \\ ${ }^{1}$ Institute of Neurolmmune Pharmacology, South Orange, NJ, United States, ${ }^{2}$ Department of Biological Sciences, Seton Hall \\ University, South Orange, NJ, United States, ${ }^{3}$ Department of Neuroscience, Temple University School of Medicine, \\ Philadelphia, PA, United States
}

Elevation of the blood ethanol concentration (BEC) to $>80 \mathrm{mg} / \mathrm{dL}(17.4 \mathrm{mM})$ after binge drinking enhances inflammation in brain and neuroimmune signaling pathways. Morphine abuse is frequently linked to excessive drinking. Morphine exerts its actions mainly via the seven transmembrane G-protein-coupled mu opioid receptors (MORs). Opioid use disorders (OUDs) include combination of opioids with alcohol, leading to opioid overdose-related deaths. We hypothesized that binge drinking potentiates onset and progression of OUD. Using C57BL/6J (B6) mice, we first characterized time-dependent inflammatory gene expression change as molecular markers using qRT-PCR within $24 \mathrm{~h}$ after binge-like exposure to high-dose, high-concentration ethanol (EtOH). The mice were given one injection of $\mathrm{EtOH}(5 \mathrm{~g} / \mathrm{kg}, 42 \% \mathrm{v} / \mathrm{v}$, i.g.) and sacrificed at $2.5 \mathrm{~h}, 5 \mathrm{~h}, 7.5 \mathrm{~h}$, or $24 \mathrm{~h}$ later. Inflammatory cytokines interleukin (IL)-1 $\beta, \mathrm{IL}-6$, and IL-18 were elevated in both the striatum (STr) and the nucleus accumbens (NAc) of the mice. We then investigated the expression profile of MOR in the STr at $2 \mathrm{~min}, 5 \mathrm{~h}$, or $24 \mathrm{~h}$ after the first $\mathrm{EtOH}$ injection and at $24 \mathrm{~h}$ and $48 \mathrm{~h}$ after the third injection. This binge-like exposure to $\mathrm{EtOH}$ upregulated MOR expression in the STr and NAc, an effect that could enhance morphine's anti-nociception. Therefore, we examined the impact of binge-like exposure to EtOH on morphine's anti-nociception at the behavioral level. The mice were treated with or without 3-d binge-like exposure to $\mathrm{EtOH}$, and the anti-nociceptive changes were evaluated using the hot-plate test $24 \mathrm{~h}$ after the final (3rd) EtOH injection with or without a cumulative subcutaneous dose $(0,0.1,0.3,1.0$, and $3.0 \mathrm{mg} / \mathrm{kg})$ of morphine at intervals of $30 \mathrm{~min}$. The response curve of the mice given $\mathrm{EtOH}$ was shifted to the left, showing enhanced latency to response to morphine up to $3 \mathrm{mg} / \mathrm{kg}$. Furthermore, co-treatment with the MOR antagonist naltrexone blocked morphine's anti-nociception in animals given either $\mathrm{EtOH}$ or saline. This confirms that MOR is involved in binge-like exposure to $\mathrm{EtOH}$-induced changes in morphine's anti-nociception. Our results suggest that $\mathrm{EtOH}$ enhanced latency to analgesic response to morphine, and such effect might initiate the onset and progression of OUDs.

Keywords: morphine, mu opioid receptors, high-dose ethanol, anti-nociception, striatum, nucleus accumbens 


\section{INTRODUCTION}

Alcohol (EtOH) is the most widely used addictive substance in the world. The effects of alcohol drinking depend on the volume consumed, the concentration by volume, and the drinking pattern (1-4). Alcohol drinking patterns refers to different frequencies and amounts of alcohol intake, such as casual drinking, binge drinking, continuous drinking, frequent heavy drinking, and episodic drinking. National Institute on Alcohol Abuse and Alcoholism (NIAAA) has defined "binge drinking" as drinking enough EtOH in a short time to elevate the blood $\mathrm{EtOH}$ concentration (BEC) to $>80 \mathrm{mg} / \mathrm{dL}$ (5); that is, $17.4 \mathrm{mM}$. Binge drinking, particularly of hard liquor ( $>40 \%$ alcohol by volume $[\mathrm{ABV}])$, is a popular activity among adolescents (6). Hard liquor was involved in $43.8 \%$ of the binge drinking reported by subjects aged 13 to 20 yrs, with vodka being the most popular beverage (7). Epidemiologic studies indicate that adolescence is a risky period for initiation of EtOH use, and early onset is associated with a greater risk of late dependence or alcoholism (8-12). Alcohol consumption by adolescents also can lead to other addictive behaviors, including abuse of various other substances such as opioids, as well as neurocognitive deficits and social impairment. These pathological conditions may lead to direct and indirect changes in the neuromaturational course extending into adulthood (8-11). Not only chronic EtOH consumption, but also sporadic consumption, such as excessive weekend drinking, can provoke cognitive-deficit neuropsychological effects in young adults (13).

Binge drinking is observed in individuals with alcohol use disorders (AUDs). Chronic/repeated alcohol use alters nociception, including changes in pain sensation (14). Moreover, binge drinking induces gut leakage causing elevation of the blood endotoxin concentration $(15,16)$. This systemic endotoxin activity can trigger activation of inflammatory cytokines and has global effects on various cell types in different organs (17, 18). Numerous investigators have shown that binge drinking in humans and binge-like exposure to $\mathrm{EtOH}$ in animals encourages production of inflammatory molecules such as interleukin (IL)- $1 \alpha$, IL-6, IL-1 $\beta$, and IL-18, as well as elevated activity of neuroimmune signaling pathways via various direct and indirect mechanisms $(19,20)$. Dysregulated continual synthesis of IL-6 has a pathological effect on chronic inflammation and autoimmunity (21). IL-1 $\beta$ is induced by pro-inflammatory signaling through Toll-like receptors (TLRs) or by cytokines, such as tumor necrosis factor (TNF)- $\alpha$, IL-1 $\beta$ itself, and the inflammasome (22).

Morphine is a powerful, highly addictive opioid drug that exerts its analgesic action mainly via mu opioid receptors (MORs) (23). The MORs are also the principal site for morphine's induction of behavioral reward $(24,25)$, locomotion (26), analgesia (27), tolerance (28), and physical dependence (29). Naltrexone is a long-lasting competitive opioid antagonist that has high affinity for MORs $(30,31)$. Oral naltrexone has been used for many years to treat opioid dependence and has been approved since 1994 by the U.S. Food and Drug Administration to treat AUDs. Tail flick latency and hot-plate analgesia tests are common assays using rodent models to examine morphine's anti-nociception (32). MORs are involved in the interaction of morphine and $\mathrm{EtOH}$, which induces neuroinflammation $(33,34)$.

We have reported that treatment with the pro-inflammatory cytokine IL-1 $\beta$ significantly increases MOR expression in endothelial cells (35) and in human U87 MG cells (36). In another in vitro study, we reported that the upregulation of MOR induced by lipopolysaccharide (LPS) stimulation in macrophage-like TPA-HL-60 cells and conditioned medium from LPS-stimulated TPA-HL-60 cells increases MOR expression in SH-SY5Y cells, a neuronal cell model, through actions mediated by TNF$\alpha$ and granulocyte-macrophage colony-stimulating factor (37). The LPS-challenged HIV-1 transgenic (HIV-1Tg) rat model with neuroinflammation demonstrates an increase in MOR expression and is more sensitive to morphine's effect in the conditioned place preference test $(38,39)$.

Taken together, considering the above-mentioned studies showing that (1) binge-like exposure to EtOH induces inflammation and inflammatory cytokines $(19,20)$ and (2) inflammatory cytokines mediate expression of MOR (35-37) and change morphine actions $(38,39)$, we hypothesized that binge-like exposure to $\mathrm{EtOH}$ increases expression of MOR and changes morphine-induced anti-nociception by inducing elevation of inflammatory molecules in the brain. In the present study, adolescent C57BL/6J mice were given binge-like exposure to high-dose, high-concentration EtOH for $3 \mathrm{~d}$ by intragastric (i.g.) injection to mimic underage binge alcohol drinking, such as over a weekend (40). The blood EtOH concentration (BEC) after single and repeated EtOH administration was measured. Time-dependent gene expression change was investigated using qRT-PCR as molecular markers to evaluate the response to this binge-like exposure to $\mathrm{EtOH}$. The nucleus accumbens (NAc) plays an important role in processing rewarding and reinforcing stimuli including drug addiction; the striatum $(\mathrm{STr})$ is part of the brain's reward circuit and a key region responsible for voluntary motor control (41). Therefore, we studied expression of the pro-inflammatory cytokine genes $I l 1 b$, Il6, and Il18, as well as the MOR gene Oprm1, in the NAc and STr. Finally, hot-plate tests were employed to evaluate the behavioral effect of binge-like exposure to EtOH on morphine's anti-nociception. The opioid antagonist naltrexone was used to confirm morphine's action on MOR. Our results suggest that neuroinflammation induced by binge-like exposure to $\mathrm{EtOH}$ contributes to elevation of morphine's anti-nociception response. Such a change might be one of the fundamental mechanisms underlying encouragement of OUDs by binge-like EtOH exposure.

\section{MATERIALS AND METHODS}

\section{Animals}

C57BL/6J mice (3-4 wks old) were purchased from the Jackson Laboratory (Bar Harbor, ME). They were housed with four animals per ventilated plastic cage (Animal Care Systems Inc., Centennial, $\mathrm{CO}$ ) and maintained in a temperature- and humidity-controlled environment. They were kept on a 12-h light/dark cycle and fed a standard rodent diet. The experimental protocol was approved by the Institutional Animal Care and Use Committee (IACUC) at Seton Hall University, South Orange, NJ. 
TABLE 1 | EtOH administration and determination of blood EtOH concentration.

\begin{tabular}{llll}
\hline Treatment & Day 1 & Day 2 & Day 3 \\
\hline Water & & Blood collection \\
EtOH 2 min & & Blood collection 2 min after injection \\
EtOH 1 d $5 \mathrm{~h}$ & & Blood collection $5 \mathrm{~h}$ after injection \\
Repeated EtOH 2 d $5 \mathrm{~h}$ & & $\mathrm{EtOH}$ & Blood collection $5 \mathrm{~h}$ after injection \\
Repeated EtOH 3 d 5h & $\mathrm{EtOH}$ & $\mathrm{EtOH}$ & Blood collection $5 \mathrm{~h}$ after injection \\
\hline
\end{tabular}

As vehicle control, water injections (not shown) were given.

\section{EtOH Treatment and BEC Determination}

The mice were allowed at least one week to adapt to the facility. To minimize the non-specific stress response to i.g. injection of $\mathrm{EtOH}$, the adolescent mice (at $\sim 5 \mathrm{wks}$ ) were given 2-day conditioning by intragastric (i.g.) injection of water. The first group of mice was then given one dose of $5 \mathrm{~g} / \mathrm{kg} / \mathrm{d}$ of $42 \%$ $\mathrm{v} / \mathrm{v}$ EtOH as a bolus via i.g. injection. Tail vein blood was collected by tail clipping prior to and at $10 \mathrm{~min}, 20 \mathrm{~min}, 1 \mathrm{~h}$, $2 \mathrm{~h}, 4 \mathrm{~h}, 6 \mathrm{~h}$, and $8 \mathrm{~h}$ after treatment. A second group of mice was designated to receive the same dose of $\mathrm{EtOH}$ for 1, 2, or 3 $\mathrm{d}$; and blood was collected $5 \mathrm{~h}$ after the last injection (Table 1 ). Plasma was obtained by centrifugation of whole blood at 10,000 $\mathrm{rpm}$ for $10 \mathrm{~min}$ at $4^{\circ} \mathrm{C}$ and stored at $-80^{\circ} \mathrm{C}$ until analysis. The EtOH concentration was determined using an Ethanol Assay Kit (Biovision, Milpitas, CA) following the manufacturer's instructions. The BEC data were analyzed using Student's $t$-test.

\section{EtOH Treatment and Tissue Collection}

After 2-day conditioning, the B6 mice were designated to receive $5 \mathrm{~g} / \mathrm{kg} 42 \% \mathrm{v} / \mathrm{v} \mathrm{EtOH}$ as a bolus one time and sacrificed at $2 \mathrm{~min}$, $2.5 \mathrm{~h}, 5 \mathrm{~h}, 7.5 \mathrm{~h}$, or $24 \mathrm{~h}$ after treatment, after which the brains were microdissected. The STr and NAc were stored at $-80^{\circ} \mathrm{C}$ until analysis. A second batch of $\mathrm{B} 6$ mice received the same dose of EtOH for 1 or 3 days (Table 2). These mice were sacrificed $5 \mathrm{~h}$ after the last injection. By adapting the $\mathrm{EtOH}$ treatment regimen as reported previously (42), we conducted preliminary studies using animals receiving water or $\mathrm{EtOH}$ for $2 \mathrm{~min}$. Other than the $\mathrm{BEC}$ reading, there are no significant differences between the readings of various assessments on the animals sacrificed immediately (2 min) after receiving $\mathrm{EtOH}(\mathrm{EtOH}$ for $2 \mathrm{~min}$ ) and those of the animals receiving water. For example, in the STr, $\Delta \mathrm{Ct}$ of $I l 1 b$ was $8.77 \pm 0.22$ in the water group and $8.51 \pm 0.58$ in the $\mathrm{EtOH}$ for 2 min group, with a fold change of $1.20 \pm$ $0.38(p=0.38)$; and in the NAc, $\Delta$ Ct of $I l 1 b$ was $9.11 \pm$ 0.52 in the water group and $9.42 \pm 0.53$ in the $\mathrm{EtOH}$ for $2 \mathrm{~min}$ group, with a fold change of $1.74 \pm 0.91(p=0.10)$. The above data were reproduced in two additional experiments. For the time course study of gene expression changes, it is necessary to include 2-min $\mathrm{EtOH}$ group that was used as control for data analysis. In line with IACUC and NIH guideline to minimize use of the animals, no water group was included in the study for Oprm1 daily expression following binge-like exposure to EtOH. As reported previously (42), we have used 2-min EtOH as control throughout this research project. Brains were microdissected,
TABLE 2 | EtOH administration timeline for Oprm1 response.

\begin{tabular}{|c|c|c|c|c|c|}
\hline Treatment & Day 1 & Day 2 & Day 3 & Day 4 & Day 5 \\
\hline $\begin{array}{l}\mathrm{EtOH} \\
2 \mathrm{~min}\end{array}$ & & & & $\begin{array}{l}\text { EtOH; } \\
\text { sacrifice } 2 \text { min } \\
\text { after injection }\end{array}$ & \\
\hline $\mathrm{EtOH} 5 \mathrm{~h}$ & & & & $\begin{array}{l}\text { EtOH; } \\
\text { sacrifice } 5 \mathrm{~h} \\
\text { after injection }\end{array}$ & \\
\hline $\begin{array}{l}\mathrm{EtOH} \\
24 \mathrm{~h}\end{array}$ & & & $\mathrm{EtOH}$ & Sacrifice & \\
\hline $\begin{array}{l}\text { Repeated } \\
\mathrm{EtOH} \\
24 \mathrm{~h}\end{array}$ & $\mathrm{EtOH}$ & $\mathrm{EtOH}$ & $\mathrm{EtOH}$ & Sacrifice & \\
\hline $\begin{array}{l}\text { Repeated } \\
\mathrm{EtOH} \\
48 \mathrm{~h}\end{array}$ & $\mathrm{EtOH}$ & $\mathrm{EtOH}$ & $\mathrm{EtOH}$ & & Sacrifice \\
\hline
\end{tabular}

As vehicle control, water injections (not shown) were given.

and the STr and NAc were collected and stored at $-80^{\circ} \mathrm{C}$ until use.

\section{RNA Isolation and cDNA Preparation}

Total RNA was extracted from the STr and NAc using the RNeasy Mini Kit (Qiagen, Germantown, MD), followed by RNase-free DNase (Qiagen) digestion to remove contaminating DNA. The RNA quality and quantity were determined using an ND1000 Nanodrop spectrophotometer (Thermo Scientific, Waltham, MA) and verified by gel electrophoresis. An equal amount of RNA (400 ng) from each sample was converted to cDNA using the $\mathrm{RT}^{2}$ First-Strand Kit (Qiagen) according to the manufacturer's instructions.

\section{qRT-PCR Analysis}

Gene expression was quantified using $\mathrm{RT}^{2}$ SYBR ROX qPCR Master Mix (Qiagen) as described previously (38, 40, 43). Realtime polymerase chain reaction (PCR) was performed with the ABI Prism 7900HT Fast Detection System (Applied Biosystems, Foster, CA). The thermocycler parameters were $95^{\circ} \mathrm{C}$ for $10 \mathrm{~min}$ followed by 40 cycles at $95^{\circ} \mathrm{C}$ for $15 \mathrm{~s}$ and $60^{\circ} \mathrm{C}$ for $1 \mathrm{~min}$. ROX was used as the passive reference. Expressions of all genes were normalized to expression of $\beta$-actin $(A c t b)$ and splicing factor, arginine/serine-rich 4 (Sfrs4). The relative expression of each gene was compared with expression of that gene in the mice given $\mathrm{EtOH}$ for $2 \mathrm{~min}$ and calculated using the $\Delta \Delta \mathrm{CT}$ method (44). The primer sequences for Illb, Il6, Oprm1, Actb, and Sfrs 4 are listed in Table 3. The Il18 primers were purchased from Qiagen (Cat No. PPM03112B). Data were analyzed using oneway ANOVA followed by Dunnett's post-tests in GraphPad Prism 5 software (GraphPad Software Inc., La Jolla, CA).

\section{EtOH Treatment and Hot-Plate Tests}

Male 5-week-old B6 mice were designated to receive either $5 \mathrm{~g} / \mathrm{kg} \mathrm{42 \%} \mathrm{v/v} \mathrm{EtOH}$ or water (control) daily for 3 days. Morphine sulfate (Sigma, St. Louis, MO) was freshly prepared prior to use by dissolving it in $0.9 \%$ sterile saline. A 1.0 $\mathrm{mg} / \mathrm{mL}$ morphine solution was serially diluted to create 
TABLE 3 | PCR array primer sequences.

\begin{tabular}{|c|c|c|}
\hline Gene symbol & Primer & Sequence $5^{\prime} 3^{\prime}$ \\
\hline \multirow[t]{2}{*}{ Oprm1 } & Forward & CCAGGGAACATCAGCGACTG \\
\hline & Reverse & GTTGCCATCAACGTGGGAC \\
\hline \multirow[t]{2}{*}{$1 / 1 b$} & Forward & AATGCCACCTIITGACAGTGATG \\
\hline & Reverse & GGAAGGTCCACGGGAAAGAC \\
\hline \multirow[t]{2}{*}{116} & Forward & CCCCAATITCCAATGCTCTCC \\
\hline & Reverse & GGATGGTCTTGGTCCTTAGCC \\
\hline \multirow[t]{2}{*}{ Actb } & Forward & GGCACCACACCTTCTACAATG \\
\hline & Reverse & GGGGTGTTGAAGGTCTCAAAC \\
\hline \multirow[t]{2}{*}{ Sfrs4 } & Forward & GATCTGAAGAACGGGTATGGCT \\
\hline & Reverse & ACACAGGTCTTGGCGTTCA \\
\hline
\end{tabular}

TABLE 4 | EtOH administration and hot-plate test timeline.

\begin{tabular}{lll}
\hline Treatment & Day 1-Day 3 & Day 4 \\
\hline Water alone & Daily water injections & Hot-plate tests \\
Water + morphine & Daily water injections & $\begin{array}{l}\text { Cumulative doses of morphine } \\
\text { (s.c.) and hot-plate tests }\end{array}$ \\
$\mathrm{EtOH}$ alone & Daily EtOH injections & Hot-plate tests \\
$\mathrm{EtOH}+$ morphine & Daily EtOH injections & $\begin{array}{l}\text { Cumulative doses of morphine } \\
\text { (s.c.) and hot-plate tests }\end{array}$
\end{tabular}

doses of $0.1,0.3,1.0$, or $3.0 \mathrm{mg} / \mathrm{kg}$. A saline solution with no morphine was the control for morphine treatment. In our preliminary studies, the animals were given cumulative doses of morphine of $0.1,0.3,1.0,3.0$, and $10 \mathrm{mg} / \mathrm{kg}$ to select the morphine doses to be used. On subcutaneously (s.c.) treatment with morphine at $10 \mathrm{mg} / \mathrm{kg}$, both control and experimental animals presented abnormal behaviors that were beyond measurement using the hot-plate test. Therefore, we chose morphine doses of $0.1,0.3,1.0$, and 3.0 $\mathrm{mg} / \mathrm{kg}$.

As shown in Table 4, on the day after Day 3 of bingelike exposure to high-dose, high-concentration $\mathrm{EtOH}$, the mice were injected subcutaneously (s.c.) with a cumulative dose of morphine as noted above at intervals of $30 \mathrm{~min}$ and placed on the hot plate of the IITC Test Analgesia Meter (Woodland Hills, CA) that was set at $55^{\circ} \mathrm{C}$. The latency was recorded according to hind-paw lick or jumping on the meter. A maximum 120-s cutoff was set to avoid tissue damage. The latency (s) was plotted against morphine doses (45). By adhering to the IACUC and NIH guideline, the minimum number of animals needed to obtain statistical power was discovered and used.

In a parallel experiment, naltrexone $(1 \mathrm{mg} / \mathrm{kg})$ was administrated s.c. $5 \mathrm{~min}$ prior to morphine injection. Hotplate test results were analyzed using two-way repeated measures ANOVA, followed by Bonferroni post-tests in GraphPad Prism 5 software (GraphPad Software Inc., La Jolla, CA) (46).

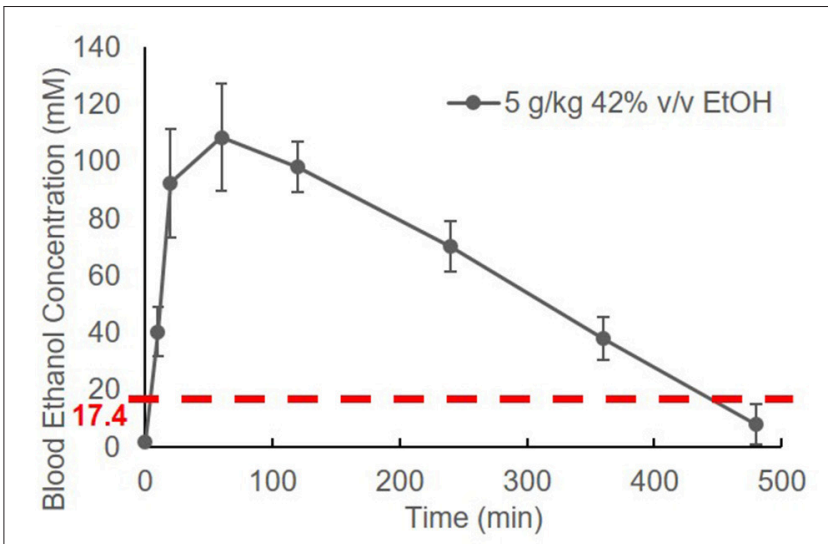

FIGURE 1 | Time course of blood EtOH concentration. Three B6 mice were given $\mathrm{EtOH}(5 \mathrm{~g} / \mathrm{kg}, 42 \% \mathrm{v} / \mathrm{v}$, i.g.). The BEC was measured prior to (0 min) and at $10 \mathrm{~min}, 20 \mathrm{~min}, 1 \mathrm{~h}, 2 \mathrm{~h}, 4 \mathrm{~h}, 6 \mathrm{~h}$, and $8 \mathrm{~h}$ later and normalized by subtracting background ( 0 min BEC) and plotted against time.

\section{RESULTS}

\section{Time Course of Blood EtOH Concentration of Mice Given Single Binge-Like Exposure to High-Dose, High-Concentration EtOH}

The BEC of adolescent C57BL/6J (B6) mice was measured prior to and at $10 \mathrm{~min}, 20 \mathrm{~min}, 1 \mathrm{~h}, 2 \mathrm{~h}, 4 \mathrm{~h}, 6 \mathrm{~h}$, and $8 \mathrm{~h}$ after $\mathrm{EtOH}$ administration. Striking elevation of the BEC to approximately $100 \mathrm{mM}$ was observed at $20 \mathrm{~min}$, and it reached a peak of $108.4 \pm$ $18.8 \mathrm{mM}$ at $1 \mathrm{~h}$. The BEC then declined gradually. After a single binge-like exposure, the time required for the animal's BEC to reach $<17.4 \mathrm{mM}$ was close to $8 \mathrm{~h}$ (Figure $\mathbf{1}$ ).

\section{Blood EtOH Concentration of Mice Given Repeated Binge-Like Exposure to High-Dose, High-Concentration EtOH}

The BEC of the adolescent B6 mice treated with $1 \mathrm{~d}, 2 \mathrm{~d}$, or $3 \mathrm{~d}$ of high-dose. high-concentration $\mathrm{EtOH}$ was determined. At 2 min after EtOH treatment, the BEC had already risen to $20.25 \pm 2.89 \mathrm{mM}$. The BEC at $5 \mathrm{~h}$ after the $1 \mathrm{st}, 2 \mathrm{nd}$, and $3 \mathrm{rd}$ $\mathrm{EtOH}$ injection were compared with that of the mice given water and at $2 \mathrm{~min}$ after EtOH injection (Figure 2A). At $5 \mathrm{~h}$ after $\mathrm{EtOH}$ administration, the BEC was significantly higher than at $2 \mathrm{~min}$ and the basal BEC of the mice given water. There was no significant difference in the $\mathrm{BEC}$ at $5 \mathrm{~h}$ after repeated $\mathrm{EtOH}$ administration on different days.

Figure 2B shows that at $24 \mathrm{~h}$ after the $3 \mathrm{rd}$ EtOH delivery, the $\mathrm{BEC}$ had returned to the basal concentration. There was no significant difference in the BEC of these mice compared with that of the mice given water.

\section{Elevated Inflammatory Molecule Expression After Single Binge-Like Exposure to High-Dose, High-Concentration EtOH}

To explore the time-dependent response of the inflammatory genes, the gene expression change in both the STr and the NAc at 


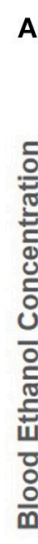

A

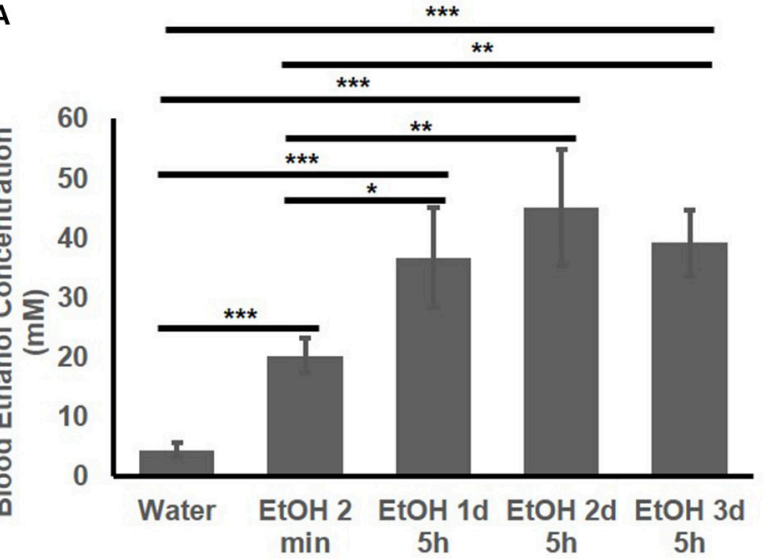

B

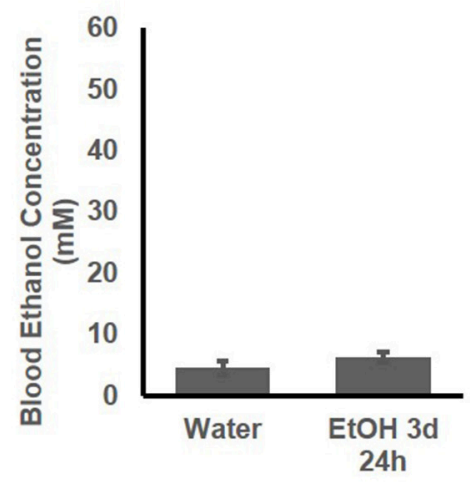

FIGURE 2 | Blood EtOH concentration after repeated EtOH administration ( 5 g/kg/d; 42\% v/v; i.g.). (A) Concentrations at $5 \mathrm{~h}$ after $1 \mathrm{st}, 2 \mathrm{nd}$, and 3rd administration. (B) $24 \mathrm{~h}$ after $3 \mathrm{~d}$ of administration, BEC was back to basal concentration. Statistical analysis was performed using student's $\mathrm{t}$ tests. ${ }^{\star} p<0.05$, ${ }^{\star \star} p<0.01$, ${ }^{\star \star \star} p<0.001 ; n=4$.

$2 \mathrm{~min}, 2.5 \mathrm{~h}, 5 \mathrm{~h}, 7.5 \mathrm{~h}$, and $24 \mathrm{~h}$ after binge-like exposure to EtOH was determined. The qRT-PCR revealed that proinflammatory genes $\operatorname{Il18}\left(\mathrm{F}_{(4,15)}=9.66, p<0.001\right)$ and $I l 1 b\left[F_{(4,14)}=3.21\right.$, $p<0.05$ ] showed significant changes in the STr within $24 \mathrm{~h}$ following EtOH exposure (Figures 3A,B). Expression of $\mathrm{Illb}$ $(p<0.05)$ and Ill8 $(p<0.01)$ increased significantly at $5 \mathrm{~h}$ after EtOH treatment; Il18 expression remained high until $24 \mathrm{~h}$ $(p<0.01)$. Within the time course of $24 \mathrm{~h}$, anti-inflammatory Il6 showed a significant change in $\mathrm{STr}\left[F_{(4,14)}=3.26, p<0.05\right]$; Il6 increased at $7.5 \mathrm{~h}$ but fell after $24 \mathrm{~h}$ in STr (Figure 3C).

Figures 3D-F shows a late response in expression of inflammatory genes $\operatorname{Il18}\left[F_{(4,14)}=11.10, p<0.001\right]$ and $I l 1 b$ $\left[F_{(4,14)}=5.85, p<0.01\right]$ in the NAc. At $7.5 \mathrm{~h}$ after bingelike exposure to high-dose, high-concentration $\mathrm{EtOH}$, proinflammatory Illb $(p<0.01)$ and Il18 expression $(p<0.001)$ was significantly elevated at $7.5 \mathrm{~h}$. Meanwhile, the extent of anti-inflammatory Il6 decreased $\left[F_{(4,14)}=0.81, p>0.05\right]$. After $24 \mathrm{~h}$, the extent of $I l 1 b, I l 18$, and Il6 expression did not show a significant difference from that in the 2-min control group.

\section{Repeated Binge-Like Exposure to High-Dose, High-Concentration EtOH Induced Upregulation of MOR Expression}

Our previous in vitro studies showed that MOR expression is induced by pro-inflammatory cytokines $(36,37)$, and therefore, we examined the time course of mRNA expression of the MOR gene Oprm1 in the STr and NAc of brains of binge-like EtOHtreated $\mathrm{B} 6$ mice at $2 \mathrm{~min}, 5 \mathrm{~h}$, or $24 \mathrm{~h}$ after the first $\mathrm{EtOH}$ infusion and at 24 and $48 \mathrm{~h}$ after the third infusion. In the STr, expression of Oprm 1 had increased significantly by $5 \mathrm{~h}$ after the first $\mathrm{EtOH}$ delivery and then gradually declined $\left[F_{(4,9)}=4.25, p<0.05\right]$; at $5 \mathrm{~h}$ after $\mathrm{EtOH}$ injection, Oprm1 expression was significantly higher than that at $2 \mathrm{~min}(p<0.05)$ (Figure 4A). Figure 4B shows a similar trend for Oprm1 in the NAc $\left[F_{(4,9)}=1.95\right.$, $p>0.05$ ] (Figure 4B).

\section{Binge-Like Exposure to High-Dose, High-Concentration EtOH Alters Morphine's Anti-nociception}

To test the behavioral consequences of the gene expression change induced by binge-like exposure to high-dose, high-concentration EtOH, hot-plate tests were performed to evaluate morphine's anti-nociception effect. $24 \mathrm{~h}$ after the $3 \mathrm{rd}$ $\mathrm{d}$ EtOH injection, the mice were injected s.c. with a cumulative dose $(0,0.1,0.3,1.0$, or $3.0 \mathrm{mg} / \mathrm{kg})$ of morphine at intervals of $30 \mathrm{~min}$ and then placed on a $55^{\circ} \mathrm{C}$ hot plate. As shown in the insert in Figure 5A, hot plate latency of the mice given either water or EtOH alone didn't change with no morphine injections. Of the mice given water, the latencies were $10.68 \pm 3.52 \mathrm{~s}$ and $10.89 \pm 2.79 \mathrm{~s}$ prior to and after injections, respectively; of the animals given $\mathrm{EtOH}$, the latency readings were $10.93 \pm$ $3.22 \mathrm{~s}$ and $10.88 \pm 4.04 \mathrm{~s}$, respectively. Morphine produced dose-dependent anti-nociception both in animals given water and in those receiving EtOH. In comparison with the animals given water (blue curve), the animals receiving $\mathrm{EtOH}$ showed a greater response to morphine; the response curve was shifted to the left $\left[F_{(4,120)}=5.73, p<0.001\right]$ (Figure 5A). The latency to analgesic response was significantly enhanced in EtOH-treated animals at $3 \mathrm{mg} / \mathrm{kg}$ dose of morphine $(p<0.001)$. The response latency induced by morphine was ablated by naltrexone in animals treated with EtOH $\left[F_{(4,72)}=42.78, p<0.001\right]$ or water $\left[F_{(4,88)}=13.20, p<0.001\right]$, and no difference was observed between animals given $\mathrm{EtOH}$ and those with water $\left[F_{(4,55)}=0.87, p>0.05\right]$ (Figure 5B).

\section{DISCUSSION}

"Binge drinking" is repeated EtOH intake causing a $\mathrm{BEC}>80$ $\mathrm{mg} / \mathrm{dL}(17.4 \mathrm{mM}$ ) (5). The peak BEC of binge drinkers, from 18 to 50 years old or older, has been reported to be as high as $470 \mathrm{mg} / \mathrm{dL}$ (that is equal to $102 \mathrm{mM}$ ) (47). In addition to the well-characterized liver toxicity, binge drinking can cause various 


\section{Striatum}
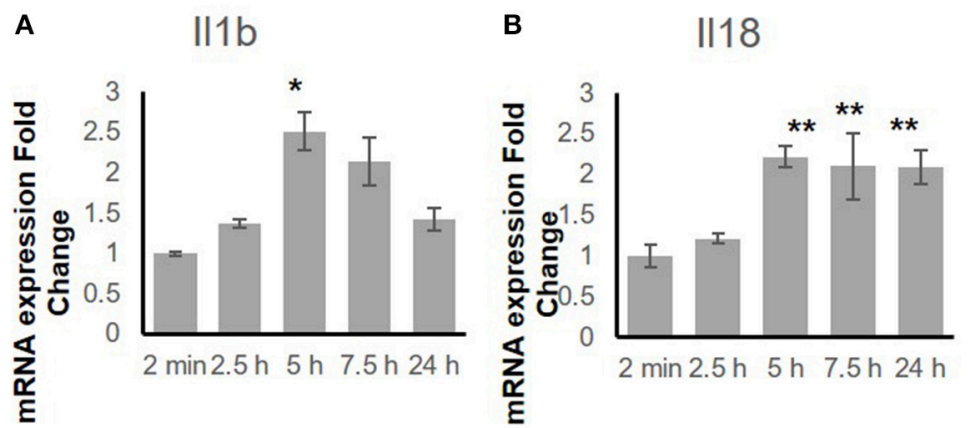

c $\quad \| 6$

\section{Nucleus Accumbens}

D

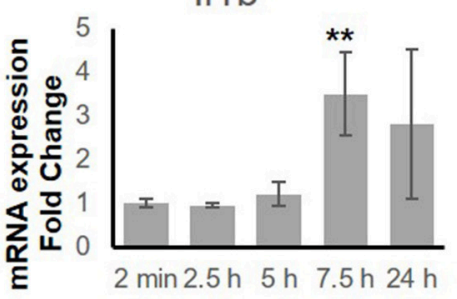

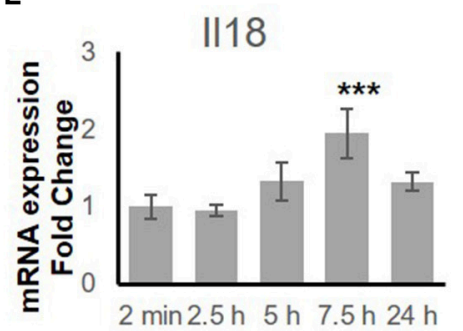

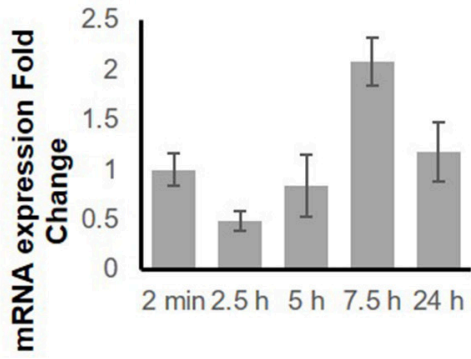

$\mathbf{F}$

$\| 6$

FIGURE 3 | Inflammation-related gene expression change in striatum (A-C) and nucleus accumbens (D-F) within $24 \mathrm{~h}$ in response to binge-like EtOH administration $(42 \% \mathrm{v} / \mathrm{v}, 5 \mathrm{~g} / \mathrm{kg}$, i.g.). Data are expressed as mean \pm SE. Statistical analysis was performed using one-way ANOVA followed by Dunnett's post-tests, compared with control 2-min EtOH group: ${ }^{\star} p<0.05,{ }^{\star *} p<0.01,{ }^{* \star *} p<0.001 ; n=4$.
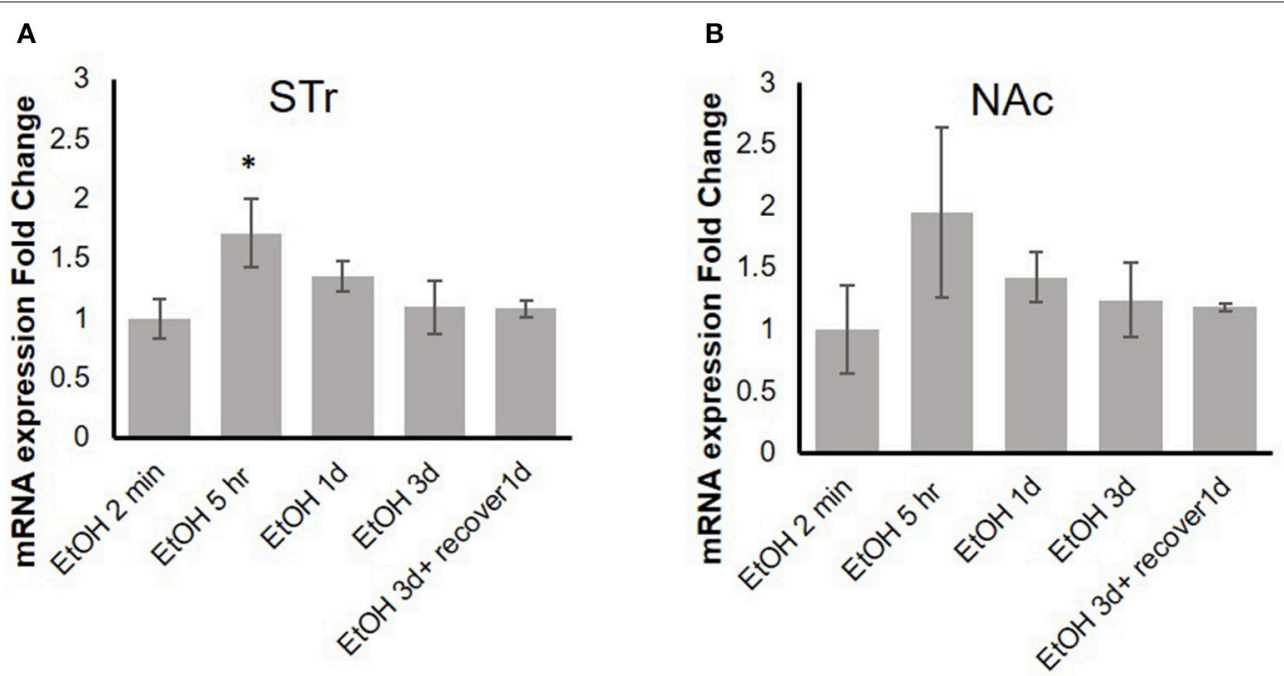

FIGURE 4 | Time-dependent expression change of MOR gene, Oprm1, in striatum (A) and nucleus accumbens (B) in response to binge-like EtOH administration (42\% v/v, $5 \mathrm{~g} / \mathrm{kg} / \mathrm{d}$, i.g.). Data are presented as mean \pm SD. Statistical analysis was performed using one-way ANOVA followed by Dunnett's post-tests compared with control 2-min EtOH group: ${ }^{\star} p<0.05 ; n=4$.

neurologic disorders (48). Morphine use/abuse frequently is linked to drinking, especially excessive drinking. Combining opioids with other substances, including EtOH, increases opioid overdose deaths (49). During the last decade, an intertwined epidemic of drug abuse and addiction, EtOH addiction, and binge drinking has emerged (50).

Alcohol research investigators have commonly used rodent models to mimic human alcohol consumption, particularly 
A

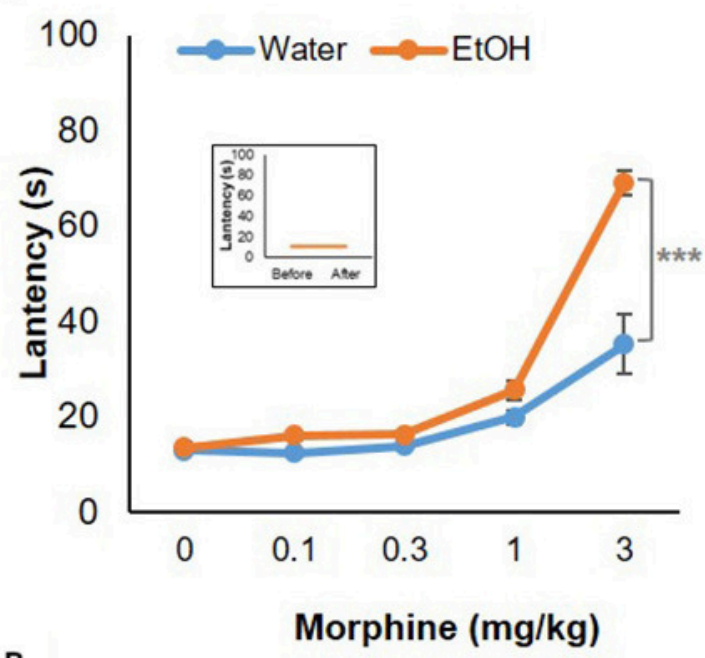

B

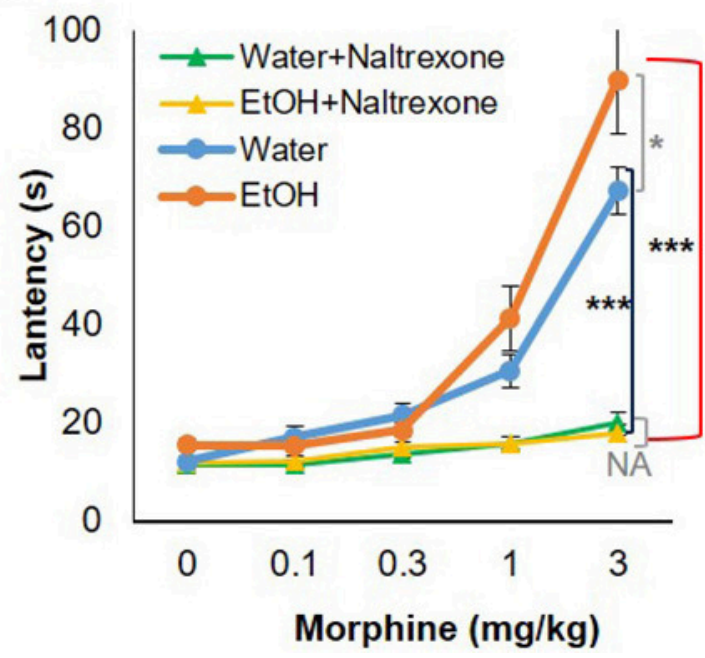

FIGURE 5 | Hot-plate analgesia test in response to morphine in 5-week-old B6 mice given 3-d binge-like EtOH treatment. (A) Ethanol-treated mice $(n=4)$ showed elevated response to morphine; morphine response curve was shifted to the left. (Insert) the animals given both water and EtOH didn't show change in latency without morphine injections $(n=4)$. (B) The response latency shift was completely ablated by opioid receptor antagonist naltrexone $(1 \mathrm{mg} / \mathrm{kg}$; s.c.) $(n=3)$. Statistical analysis was performed using two-way repeated measures ANOVA followed by Bonferroni post-tests. ${ }^{\star} p<0.05,{ }^{\star \star \star} p<0.001$.

specific drinking patterns such as binge drinking $(40,51,52)$. The high dose of EtOH we chose to administer $(5 \mathrm{~g} / \mathrm{kg} ; 42 \% \mathrm{v} / \mathrm{v})$ is equivalent to the alcohol by volume (ABV) of the hard liquors, such as vodka. By adapting the high dose of EtOH used in many rodent studies, the specified dose of EtOH was used in our study. The dose of $5 \mathrm{~g} / \mathrm{kg}$ is well-established as a binge-drinking model in mice $(40,52)$. To differentiate binge drinking in humans from the model in mice, we have used the term "binge-like exposure to EtOH." Figure 1 shows that a BEC higher than $17.4 \mathrm{mM}$ was detected in mice after one treatment (i.g.) with $\mathrm{EtOH}$ (5 $\mathrm{g} / \mathrm{kg}$ ). The elevation of BEC above $17.4 \mathrm{mM}$ was detected within 2 min (Figures 1, 2A), and the reading reached its peak, 108.4 $\pm 18.8 \mathrm{mM}$, at $1 \mathrm{~h}$. The peak declined gradually over $7-8 \mathrm{~h}$. The instant rise of BEC to the NIAAA-defined binge concentration $(17.4 \mathrm{mM})$ and the prolonged high concentration of alcohol could exert significant systemic effects, including intoxication, overburden of the liver for alcohol metabolism, and early and transient pro-inflammatory states (53-56).

Underage drinking, including binge drinking over the weekend, is common (7). To mimic the underage common drinking pattern, we chose 3-d high-dose, high-concentration $\mathrm{EtOH}$ dose. After each of the three binge-like EtOH treatments, the instant elevation of the $\mathrm{BEC}$ to $>17.4 \mathrm{mM}$ and the long duration of the elevated $\mathrm{BEC}$ followed by a reduction to below $17.4 \mathrm{mM}$ on Day 1 were also observed on Day 2 and Day 3 (Figure 2A). At the $5 \mathrm{~h}$ point, the BEC was $35-$ $40 \mathrm{mM}$ on all 3 days (Figure 2A). The 3-d binge-like exposure to EtOH therefore gave the animals the BEC $>17.4 \mathrm{mM}$ for $\sim 24 \mathrm{~h}$ in total. We previously reported that this 3 -d highdose, high-concentration EtOH binge-like regimen induces a stress response in the hippocampus of adolescent rats, and the downstream effects of the EtOH-induced stress response in the hippocampus appear to be involved in reduction of the spleen size (40).

In addition, there was a significantly higher plasma endotoxin concentration $(200 \mathrm{EU} / \mathrm{mL})$ in the animals given 3-d binge-like exposure to EtOH (40). Other studies have found that binge drinking in human subjects, as well as binge-like exposure to $\mathrm{EtOH}$ in rodents, induces gut leakage that elevates the blood endotoxin concentration $(15,16)$, which leads to production of inflammatory molecules, as well as greater activity of neuroimmune signaling pathways $(19,20)$. As noted previously, binge-like exposure to high-dose, highconcentration EtOH can trigger a severe immune response that persists even after $\mathrm{EtOH}$ has been metabolized (Figures 1, 2) (57).

After administration of $\mathrm{EtOH}$, this volatile compound distributes into the cytosol of all cells. Thus, in addition to the hippocampus in which the 3-d binge-like exposure to $\mathrm{EtOH}$ induces stress responses (40), this $\mathrm{EtOH}$ regimen is expected to affect other brain areas, including those responsible for changes in pain sensation, as it was previously reported that binge EtOH consumption increases inflammatory pain responses and mechanical and cold sensitivity (14). We focused on the STr and the NAc areas. The STr is part of the brain's reward circuit and a key region responsible for voluntary motor control $(41,58)$. The STr projects to the basal ganglia, a neuronal circuit necessary for voluntary movement control, and exerts neuronal activity related to movement, rewards, and the conjunction of movement and reward $(41,59)$. The MOR is highly expressed in the $\operatorname{STr}(60,61)$. The NAc plays an important role in the generation of motivated behaviors (62) and facilitates reward seeking by integrating neurotransmittermediated reinforcement signals with environmental stimuli $(63,64)$.

Figure 3 shows the mRNA time courses of the expression of Illb, Il18, and Il6 genes in both the STr and the NAc after one binge-like exposure to high-dose, high-concentration EtOH. 
The initial elevation of the expression these three genes in the STr appeared between 5 and $7.5 \mathrm{~h}$, whereas only $I l 18$ remained significantly elevated at $24 \mathrm{~h}$. However, in the NAc, the significant elevation of the products of these 3 genes was detected only at $7.5 \mathrm{~h}$, and the elevation did not last to $24 \mathrm{~h}$. The elevation time point and differential duration appeared to be brain-region dependent and suggest that $\mathrm{EtOH}$-mediated effects are more intense in the STr than in the NAc because the STr projects to the NAc $(65,66)$.

Previous studies have demonstrated that expression of Oprm1 is stimulated by various pro-inflammatory cytokines, including IL-1 $\beta$ (35-37). Figure 4 shows that in the STr, significant upregulation of Oprm1 was observed at $5 \mathrm{~h}$ after binge-like exposure to EtOH. On the other hand, there was only a trend to elevation of Oprm1 in the NAc. Although Oprm1 mRNA elevation disappeared by the 24-h time point, protein level of the mu opioid receptors might stay elevated; confirmation of this idea is needed. Following binge-like exposure to EtOH, inflammatory cytokines and Oprm1 mRNA levels both change in the brain areas. However, the concurrent elevation of these genes might imply, but not confirm, the direct correlation between expression of inflammatory cytokines and Oprm1 induced by high-dose, high-concentration EtOH. Our qPCR data showed that binge-like exposure to EtOH caused both neuroinflammation and upregulation of MOR in various brain areas. Further studies are on the way to examine the causal correlation between expression elevation of inflammatory cytokines and Oprm1 following binge-like exposure to $\mathrm{EtOH}$.

Elevation of Oprm1 implies increased expression and activity of MOR. Anti-nociception associated with morphine use would be the behavioral outcome of this elevation. Figure 5A shows morphine anti-nociception in adolescent C57BL/6J mice as determined by hot-plate analgesia tests at $24 \mathrm{~h}$ after 3 -d binge-like EtOH treatment. There was an increase in morphine-induced anti-nociception after the $\mathrm{EtOH}$ treatment (Figure 5). Co-treatment with naltrexone, the selective MOR antagonist, abolished anti-nociception of the cumulative dosage of morphine in the mice given either bingelike exposure to EtOH or saline. This suggests that MOR is involved in morphine's anti-nociception elevation by bingelike exposure to EtOH. This also confirms that the 3-d EtOH at a high dose $(5 \mathrm{~g} / \mathrm{kg})$ and high concentration $(42 \% \mathrm{v} / \mathrm{v})$ contributed to elevation of neuroinflammation and expression of MOR.

As noted previously, morphine abuse is frequently linked to excessive drinking. A cross-tolerance could take place between EtOH intake and treatment with morphine that is the high-affinity agonist for MOR. Le et al reported that in adult male rats, chronic EtOH consumption decreases the response to treatment with morphine (67). He et al reported that repeated $\mathrm{EtOH}$ intake by self-administration (5$6 \mathrm{~g} / \mathrm{kg} / 24 \mathrm{~h}$ ) decreases the anti-nociception of MOR agonists. Inhibition of MOR endocytosis is a possible mechanism underlying the cross-tolerance interaction between EtOH and MOR agonists (68). Shah et al reported that chronic EtOH consumption, but not a single injection that resulted in a BEC of approximately $15 \mathrm{mg} / \mathrm{dL}$, decreases the analgesic potency of opioids in mice. However, the investigators were not sure of the mechanism underlying the interaction between EtOH and opioids, including morphine (69). In examining the alleviation of CRF1 receptor antagonism related to heroin and $\mathrm{EtOH}$ dependence, Edwards et al suggested that understanding the relations between chronic exposure to addictive substances such as EtOH and pain-related states such as nociception could reveal the mechanisms underlying the transition to addiction to various substances of abuse (70). Other than the study reported by Shah et al, all these studies suggested how treatment with EtOH changed the activity of MOR and MOR-mediated morphine-induced anti-nociception. Taking these data together with the studies showing that inflammatory cytokines mediate expression of MOR (35-37) and change morphine actions $(38,39)$, we have reconciled two of our previous studies in light of our current study to address how inflammation induced by various exogenous challenges such as binge drinking might change the subject's response to morphine's anti-nociception.

In one of our previous studies, we used HIV-1 transgenic (HIV-1Tg) rats, mimicking people living with HIV/AIDS and receiving combination antiretroviral therapy (cART), to demonstrate that the persistent presence of HIV-1 proteins elevates inflammation in the brain that possibly correlates with upregulation of MOR expression and the enhancement of morphine's anti-nociception $(71,72)$. In another study, using F344 rats, we showed that repeated treatment with LPS elevates inflammation in the brain and enhances the sensitivity to morphine's anti-nociception and morphine-induced conditioned place preference (73). With binge-like exposure to high-dose, high-concentration $\mathrm{EtOH}$ in adolescent mice, with the persistent presence of HIV proteins in the HIV-1Tg rats $(71,72)$, and with repeated treatment with LPS there was enhancement of morphine's anti-nociception secondary to upregulation of MOR expression that might be the outcome of elevation of inflammation in the brain. Taken together, our three studies appear to confirm that systemic inflammation attributable to the persistence of viral proteins, repeated treatment with LPS, or binge-like exposure to EtOH leading to elevation of plasma endotoxin, enhanced the rewarding effects of morphine, both physiologically and behaviorally, thereby increasing the potential for morphine abuse and addiction.

In summary, our research indicated that binge-like exposure to high-dose, high-concentration EtOH- enhanced morphine anti-nociception might be mediated via elevation of neuroinflammation. Because morphine is highly addictive, alteration of the animals' response to its use in the course of systemic inflammation could cause the onset and progression of OUDs in the course of inflammation following binge-like exposure to $\mathrm{EtOH}$. As a result of the current study, megaanalysis using bioinformatics tools to link neuroinflammation parameters, expression of MOR, and determinants of nociception will be conducted to extend the findings of our current study. 


\section{AUTHOR CONTRIBUTIONS}

SC designed the studies; participated in data collection, data analysis, and manuscript preparation; and approved the manuscript submission. WH conducted the animal treatments and PCR array analysis and participated in tissue collection and manuscript preparation. HH conducted the hot-plate tests and participated in tissue collection. IS participated in data interpretation and manuscript preparation.

\section{REFERENCES}

1. Rehm J, Greenfield TK, Rogers JD. Average volume of alcohol consumption, patterns of drinking, and all-cause mortality: results from the US national alcohol survey. Am J Epidemiol. (2001) 153:64-71. doi: 10.1093/aje/153.1.64

2. Murray RP, Connett JE, Tyas SL, Bond R, Ekuma O, Silversides CK, et al. Alcohol volume, drinking pattern, and cardiovascular disease morbidity and mortality: is there a U-shaped function? Am J Epidemiol. (2002) 155:242-8. doi: 10.1093/aje/155.3.242

3. Mukamal KJ, Conigrave KM, Mittleman MA, Camargo CA, Stampfer MJ, Willett WC, et al. Roles of drinking pattern and type of alcohol consumed in coronary heart disease in men. N Engl J Med. (2003) 348:109-18. doi: 10.1056/NEJMoa022095

4. Shield KD, Parry C, Rehm J. Chronic diseases and conditions related to alcohol use. Alcohol Res. (2014) 35:155-73.

5. Alcoholism NIoAAa. NIAAA Council Approves Definition Of Binge Drinking. NIAAA Newsletter

6. Johnston LD, O'Malley PM, Miech RA, Bachman JG, Schulenberg JE. Monitoring the Future National Results on Drug Use: 1975-2013: Overview, Key Findings on Adolescent Drug Use. Ann Arbor: Institute for Social Research, The University of Michigan (2014).

7. Siegel M, DeJong W, Naimi TS, Fortunato EK, Albers AB, Heeren $\mathrm{T}$, et al. Brand-specific consumption of alcohol among underage youth in the United States. Alcohol Clin Exp Res. (2013) 37:1195-203. doi: 10.1111/acer.12084

8. Grant BF, Stinson FS, Harford TC. Age at onset of alcohol use and DSM-IV alcohol abuse and dependence: a 12-year follow-up. J Substance Abuse (2001) 13:493-504. doi: 10.1016/S0899-3289(01)00096-7

9. Miller JW, Naimi TS, Brewer RD, Jones SE. Binge drinking and associated health risk behaviors among high school students. Pediatrics (2007) 119:76-85. doi: 10.1542/peds.2006-1517

10. Brown SA, McGue M, Maggs J, Schulenberg J, Hingson R, Swartzwelder S, et al. A developmental perspective on alcohol and youths 16 to 20 years of age. Pediatrics (2008) 121:S290-S310. doi: 10.1542/peds.2007-2243D

11. Squeglia LM, Spadoni AD, Infante MA, Myers MG, Tapert SF. Initiating moderate to heavy alcohol use predicts changes in neuropsychological functioning for adolescent girls and boys. Psychol Addict Behav. (2009) 23:715. doi: $10.1037 / \mathrm{a} 0016516$

12. Austic E, McCabe SE, Stoddard SA, Ngo QE, Boyd C. Age and cohort patterns of medical and nonmedical use of controlled medication among adolescents. J Addict Med. (2015) 9:376-82. doi: 10.1097/ADM.0000000000000142

13. Sanhueza C, Garcia-Moreno LM, Exposito J. Weekend alcoholism in youth and neurocognitive aging. Psicothema (2011) 23:209-14.

14. Bergeson SE, Blanton H, Martinez JM, Curtis DC, Sherfey C, Seegmiller $\mathrm{B}$, et al. Binge ethanol consumption increases inflammatory pain responses and mechanical and cold sensitivity: tigecycline treatment efficacy shows sex differences. Alcoholism (2016) 40:2506-15. doi: 10.1111/acer.13252

15. Bode C, Kugler V, Bode JC. Endotoxemia in patients with alcoholic and non-alcoholic cirrhosis and in subjects with no evidence of chronic liver disease following acute alcohol excess. J Hepatol. (1987) 4:8-14. doi: 10.1016/S0168-8278(87)80003-X

16. Keshavarzian A, Farhadi A, Forsyth CB, Rangan J, Jakate S, Shaikh $\mathrm{M}$, et al. Evidence that chronic alcohol exposure promotes intestinal oxidative stress, intestinal hyperpermeability and endotoxemia prior to

\section{FUNDING}

This research was partially supported by National Institutes of Health grants AA025398 (IS); DA07058, AA023172 and AA025964 (SC).

\section{ACKNOWLEDGMENTS}

The authors thank Wenjuan Du for her assistance in collecting tissues, and Judith Gunn Bronson, MS, FSTC for the excellent editing.

development of alcoholic steatohepatitis in rats. J Hepatol. (2009) 50:538-47. doi: 10.1016/j.jhep.2008.10.028

17. Szabo G, Bala S, Petrasek J, Gattu A. Gut-liver axis and sensing microbes. Digest Dis. (2010) 28:737-44. doi: 10.1159/000324281

18. Bala S, Marcos M, Gattu A, Catalano D, Szabo G. Acute binge drinking increases serum endotoxin and bacterial dna levels in healthy individuals. PLoS ONE (2014) 9:e96864. doi: 10.1371/journal.pone. 0096864

19. Molina PE, Happel KI, Zhang P, Kolls JK, Nelson S. Focus on: alcohol and the immune system. Alcohol Res Health (2010) 33:97-108.

20. Lehnert M, Kovacs EJ, Molina PE, Relja B. Modulation of inflammation by alcohol exposure. Media Inflammat. (2014) 2014:283756. doi: 10.1155/2014/283756

21. Tanaka T, Narazaki M, Kishimoto T. IL-6 in inflammation, immunity, and disease. Cold Spring Harbor Perspect Biol. (2014) 6:a016295. doi: 10.1101/cshperspect.a016295

22. Wang Y, Li Y-B, Yin J-J, Wang Y, Zhu L-B, Xie G-Y, et al. Autophagy regulates inflammation following oxidative injury in diabetes. Autophagy (2013) 9:272-7. doi: 10.4161/auto.23628

23. Pasternak GW. Pharmacological mechanisms of opioid analgesics. Clin Neuropharmacol. (1993) 16:1-18.

24. Chiara GD, Alan North R. Neurobiology of opiate abuse. Trends Pharmacol Sci. (1992) 13:185-93. doi: 10.1016/0165-6147(92)90062-B

25. Wise RA. Neurobiology of addiction. Curr Opin Neurobiol. (1996) 6:243-51.

26. Stevens KE, Mickley GA, McDermott LJ. Brain areas involved in production of morphine-induced locomotor hyperactivity of the C57B1/6J mouse. Pharmacol Biochem Behav. (1986) 24:1739-47. doi: 10.1016/0091-3057(86)90514-9

27. Porreca F, Burks TF. Supraspinal opioid receptors in antinociception. In: Herz A, Akil H, Simon EJ, editors. Opioids II Berlin, Heidelberg: Springer Berlin Heidelberg (1993). p 21-51.

28. Aghajanian GK. Tolerance of locus coeruleus neurones to morphine and suppression of withdrawal response by clonidine. Nature (1978) 276:186-8. doi: $10.1038 / 276186 \mathrm{a} 0$

29. Johnson SM, Fleming WW. Mechanisms of cellular adaptive sensitivity changes: applications to opioid tolerance and dependence. Pharmacol Rev. (1989) 41:435-88.

30. Raynor K, Kong H, Chen Y, Yasuda K, Yu L, Bell GI, et al. Pharmacological characterization of the cloned kappa-, delta-, and mu-opioid receptors. Mol Pharmacol. (1994) 45:330-4.

31. Steinmiller CL, Young AM. Pharmacological Selectivity of CTAP in a warm water tail-withdrawal antinociception assay in rats. Psychopharmacology (2008) 195:497-507.

32. Bannon AW, Malmberg AB. Models of nociception: hot-plate, tail-flick, and formalin tests in rodents. Curr Protocols Neurosci. (2007) Chapter 8:Unit 8.9.doi: 10.1002/0471142301.ns0809s41

33. Corrigan F, Wu Y, Tuke J, Coller JK, Rice KC, Diener KR, et al. Alcohol-induced sedation and synergistic interactions between alcohol and morphine: a key mechanistic role for Toll-Like Receptors and MyD88-dependent signalling. Brain Behav Immunity (2015) 45:245-52. doi: 10.1016/j.bbi.2014.12.019

34. Shrivastava P, Cabrera MA, Chastain LG, Boyadjieva NI, Jabbar S, Franklin $\mathrm{T}$, et al. $\mathrm{Mu}$-opioid receptor and delta-opioid receptor differentially regulate microglial inflammatory response to control proopiomelanocortin neuronal 
apoptosis in the hypothalamus: effects of neonatal alcohol. J Neuroinflamma. (2017) 14:83. doi: 10.1186/s12974-017-0844-3

35. Vidal EL, Patel NA, Wu G, Fiala M, Chang SL. Interleukin-1 induces the expression of mu opioid receptors in endothelial cells. Immunopharmacology (1998) 38:261-6. doi: 10.1016/S0162-3109(97)00085-4

36. Byrne LS, Peng J, Sarkar S, Chang SL. Interleukin-1 beta-induced up-regulation of opioid receptors in the untreated and morphinedesensitized U87 MG human astrocytoma cells. J Neuroinflamma. (2012) 9:252. doi: 10.1186/1742-2094-9-252

37. Langsdorf EF, Mao X, Chang SL. A role for reactive oxygen species in endotoxin-induced elevation of MOR expression in the nervous and immune systems. J Neuroimmunol. (2011) 236:57-64. doi: 10.1016/j.jneuroim.2011.05.009

38. Homji NF, Mao X, Langsdorf EF, Chang SL. Endotoxin-induced cytokine and chemokine expression in the HIV-1 transgenic rat. J Neuroinflamm. (2012) 9:3-3. doi: 10.1186/1742-2094-9-3

39. Homji NF, Vigorito M, Chang SL. Morphine-induced conditioned place preference and associated behavioural plasticity in HIV-1 transgenic rats. Int J Clin Exp Med. (2012) 5:105-23.

40. Liu X, Connaghan KP, Wei Y, Yang Z, Li MD, Chang SL. Involvement of the hippocampus in binge ethanol-induced spleen atrophy in adolescent rats. Alcoholism Clin Exp Res. (2016) 40:1489-500. doi: 10.1111/acer. 13109

41. Baez-Mendoza R, Schultz W. The role of the striatum in social behavior. Front Neurosci. (2013) 7:233. doi: 10.3389/fnins.2013.00233

42. Chang SL, Patel NA, Romero AA. Activation and desensitization of Fos immunoreactivity in the rat brain following ethanol administration. Brain Res. (1995) 679:89-98. doi: 10.1016/0006-8993(95) 00210-H

43. Yang Z, Nesil T, Connaghan KP, Li MD, Chang SL. Modulation effect of HIV1 Viral proteins and nicotine on expression of the immune-related genes in brain of the hiv-1 transgenic rats. J Neuroimmune Pharmacol. (2016) 11:562-71. doi: 10.1007/s11481-016-9679-4

44. Winer J, Jung CK, Shackel I, Williams PM. Development and validation of real-time quantitative reverse transcriptase-polymerase chain reaction for monitoring gene expression in cardiac myocytes in vitro. Anal Biochem. (1999) 270:41-9. doi: 10.1006/abio.1999.4085

45. Nealon CM, Patel C, Worley BL, Henderson-Redmond AN, Morgan DJ, Czyzyk TA. Alterations in nociception and morphine antinociception in mice fed a high-fat diet. Brain Res Bull. (2018) 138:64-72. doi: 10.1016/j.brainresbull.2017.06.019

46. Masocha W, Kombian SB, Edafiogho IO. Evaluation of the antinociceptive activities of enaminone compounds on the formalin and hot plate tests in mice. Sci Rep. (2016) 6:21582 doi: 10.1038/srep21582

47. Cucciare MA, Darrow M, Weingardt KR. Characterizing binge drinking among US military Veterans receiving a brief alcohol intervention. Addict Behav. (2011) 36:362-7. doi: 10.1016/j.addbeh.2010. 12.014

48. Nesic J, Duka T. Binge drinking and withdrawal: neural mechanisms in humans a2. In: Biological Research on Addiction. San Diego, CA: Academic Press (2013). p 333-40.

49. Kandel DB, Hu MC, Griesler P, Wall M. Increases from 2002 to 2015 in prescription opioid overdose deaths in combination with other substances. Drug Alcohol Depend. (2017) 178:501-11. doi: 10.1016/j.drugalcdep.2017.05.047

50. Miller JW, Gfroerer JC, Brewer RD, Naimi TS, Mokdad A, Giles WH. Prevalence of adult binge drinking: a comparison of two national surveys. Am J Prevent Med. (2004) 27:197-204. doi: 10.1016/j.amepre.2004. 05.004

51. Brandon-Warner E, Schrum LW, Schmidt CM, McKillop IH. Rodent models of alcoholic liver disease: of mice and men. Alcohol (2012) 46:715-25. doi: 10.1016/j.alcohol.2012.08.004

52. Bertola A, Mathews S, Ki SH, Wang H, Gao B. Mouse model of chronic and binge ethanol feeding (the NIAAA model). Nat Protocols (2013) 8:627. doi: 10.1038/nprot.2013.032

53. Waszkiewicz N, Szulc A. Immunity defects in acute and chronic alcohol intoxication. Pol Merkur Lekarski (2010) 29:269-73.

54. Hillbom M, Saloheimo P, Juvela S. Alcohol consumption, blood pressure, and the risk of stroke. Curr Hyperten Rep. (2011) 13:208-13. doi: 10.1007/s11906-011-0194-y
55. Yun JW, Son MJ, Abdelmegeed MA, Banerjee A, Morgan TR, Yoo SH, et al. Binge alcohol promotes hypoxic liver injury through a CYP2E1-HIF-1alphadependent apoptosis pathway in mice and humans. Free Radical Biol Med. (2014) 77:183-94. doi: 10.1016/j.freeradbiomed.2014.08.030

56. Afshar M, Richards S, Mann D, Cross A, Smith GB, Netzer G, et al Acute immunomodulatory effects of binge alcohol ingestion. Alcohol (2015) 49:57-64. doi: 10.1016/j.alcohol.2014.10.002

57. Horner C, Bouchon A, Bierhaus A, Nawroth PP, Martin E, Bardenheuer HJ, et al. Role of the innate immune response in sepsis. Der Anaesthesist (2004) 53:10-28. doi: 10.1007/s00101-003-0626-4

58. Yager LM, Garcia AF, Wunsch AM, Ferguson SM. The ins and outs of the striatum: role in drug addiction. Neuroscience (2015) 301:529-41. doi: 10.1016/j.neuroscience.2015.06.033

59. Hollerman JR, Tremblay L, Schultz W. Influence of reward expectation on behavior-related neuronal activity in primate striatum. J Neurophysiol. (1998) 80:947-63. doi: 10.1152/jn.1998.80.2.947

60. Chaturvedi K. Opioid peptides, opioid receptors and mechanism of down regulation. Indian J Exp Biol. (2003) 41:5-13.

61. Le Merrer J, Becker JA, Befort K, Kieffer BL. Reward processing by the opioid system in the brain. Physiol Rev. (2009) 89:1379-412. doi: 10.1152/physrev.00005.2009

62. Nicola SM. The nucleus accumbens as part of a basal ganglia action selection circuit. Psychopharmacology (2007) 191:521-50 doi: 10.1007/s00213-006-0510-4

63. Stuber GD, Klanker M, de Ridder B, Bowers MS, Joosten RN, Feenstra MG, et al. Reward-predictive cues enhance excitatory synaptic strength onto midbrain dopamine neurons. Science (2008) 321:1690-2. doi: $10.1126 /$ science. 1160873

64. Brown HD, McCutcheon JE, Cone JJ, Ragozzino ME, Roitman MF. Primary food reward and reward-predictive stimuli evoke different patterns of phasic dopamine signaling throughout the striatum. Eur J Neurosci. (2011) 34:1997-2006. doi: 10.1111/j.1460-9568.2011.07914.x

65. Quintero GC. Role of nucleus accumbens glutamatergic plasticity in drug addiction. Neuropsychiatr Dis Treat. (2013) 9:1499-512. doi: 10.2147/NDT.S45963

66. Navratilova E, Atcherley C, Porreca F. Brain circuits encoding reward from pain relief. Trends Neurosci. (2015) 38:741-50. doi: 10.1016/j.tins.2015.09.003

67. Le AD, Khanna JM, Kalant H, LeBlanc AE. Cross-tolerance between ethanol and morphine. Adv Exp Med Biol. (1980) 132:771-7.

68. He L, Whistler JL. Chronic ethanol consumption in rats produces opioid antinociceptive tolerance through inhibition of $\mathrm{Mu}$ opioid receptor endocytosis. PLoS ONE (2001) 6:e19372. doi: 10.1371/journal.pone.0019372

69. Shah S, Duttaroy A, Sehba F, Chen B, Philippe J, Monderson T, et al. The effect of ethanol drinking on opioid analgesia and receptors in mice. Alcohol (1997) 14:361-6. doi: 10.1016/S0741-8329(96)00184-X

70. Edwards S, Vendruscolo LF, Schlosburg JE, Misra KK, Wee S, Park PE, et al. Development of mechanical hypersensitivity in rats during heroin and ethanol dependence: alleviation by CRF1 receptor antagonism. Neuropharmacology (2012) 62:1142-51. doi: 10.1016/j.neuropharm.2011.11.006

71. Chang S, Vigorito M. Role of HIV-1 infection in addictive behavior: a study of a HIV-1 transgenic rat model. Am J Infect Dis. (2006) 2:98-106. doi: 10.3844 /ajidsp.2006.98.106

72. Chang SL, Connaghan KP. Behavioral and molecular evidence for a feedback interaction between morphine and HIV-1 viral proteins. J Neuroimmune Pharmacol. (2012) 7:332-40. doi: 10.1007/s11481-011-9324-1

73. Chang S, Sarkar S, Vigorito M, Mao X. Endotoxin enhancement of morphineinduced conditioned place preference. Int J Clin Exp Med. (2016) 5:105-23. doi: $10.4303 /$ jdar $/ 235950$

Conflict of Interest Statement: The authors declare that the research was conducted in the absence of any commercial or financial relationships that could be construed as a potential conflict of interest.

Copyright $\odot 2019$ Chang, Huang, Han and Sariyer. This is an open-access article distributed under the terms of the Creative Commons Attribution License (CC BY). The use, distribution or reproduction in other forums is permitted, provided the original author(s) and the copyright owner(s) are credited and that the original publication in this journal is cited, in accordance with accepted academic practice. No use, distribution or reproduction is permitted which does not comply with these terms. 